\title{
Violent criminal death involving face, head and neck: processes, expert reports and
} epidemiological data

\author{
Morte criminal violenta acometendo face, cabeça e pescoço: processos, laudos periciais e dados \\ epidemiológicos
}

Muerte criminal violenta que involucra rostro, cabeza y cuello: juicios, peritajes y datos

epidemiológicos

Received: 02/17/2021 | Reviewed: 02/28/2021 | Accept: 03/05/2021 | Published: 03/11/2021

Luiza Monachini Marcantonio
ORCID: https://orcid.org/0000-0003-4479-057X
São Paulo State University, Brazil
E-mail: luizamarcantonio@hotmail.com
Clemente Maia da Silva Fernandes
ORCID: https://orcid.org/0000-0002-5401-6265
São Paulo State University, Brazil
E-mail: c.face@terra.com.br
Karla Regina Horti Campos de Freitas
ORCID: https://orcid.org/0000-0002-1433-6846
E-mail: karlacampoulks @gate, Brazil
Mônica da Costa Serra
Superintendence of the Technical-Scientific Police
ORCID: https://orcid.org/0000-0001-8820-2982
São Paulo State University, Brazil
E-mail: monica.serra@unesp.br

\begin{abstract}
In criminal lawsuits, the magistrate often needs technical contribution of an expert on the subject related to the crime, for the application of the penal sanction. This study aimed to analyze lawsuits, expert reports and epidemiological data of violent death cases, in which there was involvement of the face, head and neck in the region that covered by the Legal Medical Institute (LMI) of Araraquara-SP. For this purpose, decisions of the Court of Justice of São Paulo State were researched, in the period from 2012 to September 2017. The judgments were read and those related to consummated homicide, body injury followed by death and robbery were selected. The expert reports corresponding to the selected cases were searched in the LMI of Araraquara. This search resulted in 49 reports, which were analyzed. We observed that the majority of homicide and robbery victims were male, white, under 40 years of age and of low education level. The epidemiological data found were consistent with the data presented by Brazilian government agencies. The expert reports analyzed were performed exclusively by medical examiners, using technical language and detailed description of the lesions and the instruments that caused them. The most frequent causes of death were traumatic brain injury (41.67\%), multiple trauma (10.42\%), hemorrhagic shock (10.42\%) and anemia $(10.42 \%)$. The most frequent instruments, which caused injuries, were the perforating-blunt (26.42\%), the forceful (22.64\%) and the perforatingcutting $(20.75 \%)$. In general, the reports presented good quality, tending to be of great help for the clarification of criminal justice.
\end{abstract}

Keywords: Forensic dentistry; Expert testimony; Violence; Forensic sciences; Criminal law.

\section{Resumo}

Nos processos criminais muitas vezes o magistrado precisa do aporte técnico de um expert no assunto relacionado ao crime sub judice para a aplicação da sanção penal. O objetivo desse trabalho foi analisar processos, laudos periciais e dados epidemiológicos de casos de mortes violentas, em que houve acometimento da região de face, cabeça e pescoço na região de abrangência do Instituto Médico Legal (IML) de Araraquara. Para isto foram levantadas, primeiramente, decisões do Tribunal de Justiça de São Paulo (TJSP), no período de 2012 a setembro de 2017. Os acórdãos foram lidos e selecionados os que tratavam de homicídio, lesão corporal seguida de morte e latrocínio consumados. Os laudos periciais correspondentes aos processos levantados foram buscados no IML de Araraquara, resultando em 49 laudos, que foram analisados. Observou-se que a maioria das vítimas de homicídio e latrocínio era homem, branco, com menos de 40 anos de idade e de baixa escolaridade. Os dados epidemiológicos encontrados foram condizentes com os dados apresentados por órgãos governamentais. Os laudos periciais analisados foram realizados exclusivamente por médicos 
legistas, com uso de linguagem técnica e com descrição detalhada das lesões e dos instrumentos que as causaram. As causas de morte mais frequentes foram: traumatismo crânio encefálico (41.67\%), politraumatismo (10,42\%), choque hemorrágico $(10,42 \%)$ e anemia $(10,42 \%)$. Os instrumentos causadores de lesões mais frequentes foram os pérfurocontundentes $(26,42 \%)$, os contundentes $(22,64 \%)$ e os pérfuro cortantes $(20,75 \%)$. No geral, os laudos avaliados apresentaram boa qualidade, tendendo a ser um grande auxiliar para o deslinde da justiça criminal.

Palavras-chave: Odontologia legal; Prova pericial; Violência; Ciências forenses; Direito penal.

\section{Resumen}

En los casos penales, el magistrado a menudo necesita el apoyo técnico de un experto en el tema relacionado con el delito sub judice para la aplicación de la sanción penal. El objetivo de este trabajo fue analizar procesos, peritajes y datos epidemiológicos de casos de muertes violentas, en los que el rostro, la cabeza y el cuello fueron afectados en la región amparada por el Instituto Médico Legal (IML) de Araraquara. En este sentido, las decisiones fueron planteadas por primera vez por la Corte de Justicia de São Paulo (TJSP), de 2012 a septiembre de 2017. Las sentencias fueron leídas y seleccionadas fueron las relacionadas con homicidio, lesiones corporales seguidas de muerte consumada y robo. Los informes periciales correspondientes a los casos planteados fueron buscados en el IML de Araraquara, dando como resultado 49 informes, que fueron analizados. Se observó que la mayoría de víctimas de homicidio y robo fueron hombres, blancos, menores de 40 años y con bajo nivel educativo. Los datos epidemiológicos encontrados fueron consistentes con los datos presentados por agencias gubernamentales. Los informes periciales analizados fueron elaborados exclusivamente por médicos forenses, en lenguaje técnico y con descripción detallada de las lesiones y los instrumentos que las ocasionaron. Las causas de muerte más frecuentes fueron: traumatismo craneoencefálico $(41,67 \%)$, politraumatismo $(10,42 \%)$, shock hemorrágico $(10,42 \%)$ y anemia $(10,42 \%)$. Los instrumentos causantes de lesiones más frecuentes fueron perforaciones romas $(26,42 \%)$, romas $(22,64 \%)$ y cortantes $(20,75 \%)$. En general, los informes evaluados fueron de buena calidad, tendiendo a ser de gran ayuda para el establecimiento de la justicia penal.

Palabras clave: Odontología forense; Testimonio de experto; Violencia; Ciencias forenses; Derecho penal.

\section{Introduction}

Violence, a set of actions by one or more individuals that cause physical or psychological harm to themselves or others, presents a chronic problem in social, economic and political structures, posing risk to the human development process, with potential threats life and health and, consequently, the possibility of death (Oliveira, 2008; Reichenheim et al., 2011; Magnabosco et al., 2020; Ribeiro \& Laureano Filho, 2020).

Its impact can be verified worldwide in several ways. Each year more than one million people lose their lives, and many more suffer non-fatal injuries resulting from self-harm, interpersonal aggression or collective violence. In general, violence is estimated to be a leading cause of death for people aged 15-44 worldwide (Dahlberg \& Krug, 2006).

In Brazil, mortality due to homicides attracts attention, fundamentally because, in addition to occurring in large numbers, it reaches, in most cases, a young and low-income population (Costa, 1999). According to United Nations Organization (UN) data, for 2009, the homicide rate in Brazil was among the highest in the world, with 22.7 homicides for 100,000 inhabitants, occupying the third place in South America (Estelita et al., 2013). Brazil has a number almost five times higher than the world index, which is 6.2 (Borges et al., 2013). In 2011 there were 14 Brazilian cities listed among the 50 most violent in the world. This number raised to 15 in 2012 and 16 in 2013 and in 2014 reached the number of 19 cities among the most violent in the planet (Gomes, 2015).

Report from the "Agência Brasil" website brings data from the Brazilian Public Safety Yearbook of 2016, a survey carried out by the Brazilian Forum of Public Security, showing that in Brazil there were 278,839 cases of willful homicide, robbery and body injury followed by death and deaths resulting from police intervention, from January 2011 to December 2015 , while in Syria, in the same period, there were 256,124 violent deaths, according to the Syrian Human Rights Observatory (Bocchini, 2017). The most recent version of the Yearbook, published in October 2019, shows that there was a 10.8\% decrease in the number of intentional lethal violent crimes between the years of 2017 and 2018. There were 27.5 deaths per 100,000 inhabitants (Fórum Brasileiro de Segurança Pública, 2019).

Among the intentional crimes that result in death, the most common are homicide, robbery and bodily injury followed 
by death. Usually the region that is most affected is the face, head and neck, the area of practice of the dental surgeon. These crimes are typified in the Brazilian Penal Code (Brasil, 1940; Greco, 2020).

In criminal cases, the technical knowledge of the subject related to the crime is often crucial for the clarification of the bench for the proper application of criminal sanction. Such knowledge is provided by experts, in their expert reports, arising from expert examination carried out by them (Silva, 1997; Couto, 2011; Krymchantowski et al., 2011; Croce \& Croce Jr, 2012; Serra \& Fernandes, 2013; França, 2017; Vanrell, 2019; Carvalho \& Almeida, 2020; Lopes, 2020; Oliveira et al., 2021).

They correspond to the written and detailed narration of all the operations of an expert, determined by police or judicial authority, to one or more professionals previously named and committed in the form of the law (Espindola, 2008; Lopes, 2020; Carvalho \& Almeida, 2020). Proper preparation of expert reports is conditio sine qua non (of paramount importance) for the clarification and application of Justice, in cases that may be necessary.

The expert's report is then the final result of a complete and detailed technical-scientific work, which objective is to subsidize the Justice in matters that have raised doubts in the process. There are reports intended to the Criminal Justice, whose main characteristic is that all parts of the process are used, as it is an unique technical-expert piece. There is only the figure of the official expert to make the expertise (with only one exception provided for in the Code of Criminal Procedure), which report can be used since the police investigation phase until the process - this, either by the bench, prosecutor or parties represented by their lawyer (Espindola, 2008; Bandeira et al., 2013; Carvalho \& Almeida, 2020; Oliveira et al., 2021). The proper preparation of such reports is of great importance in the criminal process. And the pronouncement of the sentence, based on an award of excellent quality, ensures the due process of justice.

Criminal investigations in the state of São Paulo are carried out by the Scientific Police, which is a subordinate body to the Secretary of State for Public Security Affairs, also responsible for the military and civil police. Within the scientific police there are the Institutes of Criminology (ICs) and the Legal Medical Institutes (IMLs) (Superintendência da Polícia Técnico Científica, 2021).

The face, area of expertise of Dentistry, is often targeted by those seeking to injure or even kill their victims.

In cases of violent death, it is obligatory to carry out an examination of the body in order to verify, among other things, the cause of death and the instrument that caused it. To this expertise, the Criminal Procedure Code (CPC) (Brasil, 1941) gives the name necropsy, and who carries it out is the IMLs (Superintendência da Polícia Técnico Científica, 2021).

Forensic reports are essential for the trial of homicide cases. prosecution of homicide cases. A good procedural setting of expert evidence convinces jurors and produces lawful judgments (Diniz et al., 2013). The expert evidence is fundamental for the occurrence of a fair, legal and coherent criminal procedure (Dias, 2010). However, studies to determine the importance and quality of the expert report in judicial decisions are scarce (Martinez, 2013). This study aimed to analyze cases, expert reports and epidemiological data of cases of violent deaths resulting from homicide, robbery and bodily injury followed by death, in the region of the city of Araraquara, State of São Paulo, from January 2012 to September 2017, in which there has been involvement of the region of face, head and neck, and its importance for criminal justice.

\section{Methodology}

The present research corresponds to a documentary study, with an observational, retrospective, epidemiological exploratory design, with a cross-sectional and quantitative approach, as presented by Pereira et al. (2018). It was approved by the Committee of Ethics in Research in Human Beings of the Faculty of Dentistry of Araraquara - UNESP (CAAE $n$. 75941317.8.0000.5413).

The development of this project was divided into two stages: in the first phase, second instance decisions were taken, 
from criminal cases originating in the State of São Paulo, from January 2012 to September 2017, of violent death cases in which the regions of the face, head and neck have been affected; in the second stage, the expert reports corresponding to the lawsuits were analyzed, referring to expert reports carried out at the Legal Medical Institute of Araraquara-SP.

For the first stage of the research, the tool of consultation of jurisprudence of the website of the Court of Justice of São Paulo was used, using the following parameters in the mechanism of search filtering:

a) Class: criminal review and appeal. The purpose of this filter was to exclude processes that were still in process at the first instance.

b) Subject: simple homicide, privileged homicide, qualified homicide, bodily injury followed by death and robbery.

c) In the comarca field, were selected those whose competence to perform the expert examinations was from the Legal Medical Institute of Araraquara-SP: Américo Brasiliense, Araraquara, F.D. Américo Brasiliense/Araraquara, F.D. Iacanga/Ibitinga, F.D. Tabatinga/Ibitinga, Ibitinga, Itápolis, Matão and Santa Lucia / Araraquara.

The judgments were read and those dealing with crimes of homicide, bodily injury and robbery consummated, involving violent deaths in which there has been involvement of the face, head and neck region during the established time interval were selected.

Another criterion of exclusion corresponded to attempted crimes, that is, only the crimes committed (in which there was death) were included.

In the judicial decisions included in the present study, it was verified:

a) If reference was made to the criminal expert's report;

b) If there is reference, if the award in question was used to support the decision;

c) If there is reference, if in the judicial decision there was mention of specific information of the report.

After the first phase of the research, the second phase began, with the search of the expert reports in the IML of Araraquara-SP.

In the raised reports, the following information was sought:

a) The age, gender, ancestry or color of the skin and the degree of education of the victim;

b) Who was the professional who acted in the expertise;

c) If technical language was used;

d) If there was reference to the cause of death;

e) What was the cause of death;

f) If the description and classification of the injuries and instruments that caused them were present;

It was also verified whether the crimes corresponded to cases of domestic violence, and whether the use of illicit drugs was mentioned.

The results are presented through descriptive statistics.

The epidemiological data obtained in the data collected in this study, related to age, gender and skin color of the victims, as well as to the criminal type, were compared with the epidemiological data obtained from government agencies (Brazilian Institute of Geography and Statistics - IBGE - and Public Security Secretariat of São Paulo - SSP/SP). The proportions of segmented prevalence in age, gender, skin color and type of crime were compared using the chi-square test (gender and criminal type) and Fisher's exact test (age group and skin color). GraphPad Prism 6 software (San Diego, CA, USA) was used for statistical analysis of the data, and all statistical tests were applied at a significance level of $5 \%$. 


\section{Results}

The search on the website of the Court of Justice of São Paulo with the pre-determined parameters, until September 4, 2017 resulted in 360 processes found.

Of these, 116 were prior to 2012 and were therefore excluded without any analysis. The remaining 244 cases were analyzed and 90 were excluded because they dealt with unconsummated crimes. Of the remaining 154 completed felony cases, 28 treated lesions in other regions that did not involve the face, head, and neck, and were also excluded. After applying the exclusion criteria, there were 126 processes to be analyzed.

Of the 126 cases included in our sample, 18 (14.29\%) were judged in 2012, 35 (27.78\%) in 2013, 18 (14.29\%) in 2014, $22(17.46 \%)$ in 2015, $21(16.67 \%)$ in 2016 and 12 (9.52\%) in 2017, as can be seen in graphic 3

The majority of the cases were from Araraquara (77.78\%), followed by Matão (7.14\%), Itápolis (5.56\%) and Américo Brasiliense and Ibitinga (both with 4.76\%). No processes were found from Iacanga, Tabatinga and Santa Lúcia.

Regarding the criminal type, $82.54 \%$ of the cases found (104 cases) were related to homicide crimes and $17.46 \%$ ( 22 cases) to robberies. No crime of bodily injury followed by death was found.

Of the 126 judgments analyzed, 77 (61.11\%) referred to the necroscopic report and 49 (38.89\%) did not mention any type of award. Of these 77, all referred to the award as a way of proving the materiality of the crime.

It was observed that the references to the reports occurred mainly to demonstrate the materiality of the crime. Some judgements transcribed parts of the respective expert reports, thus presenting specific information contained therein.

After the first stage of the research, we searched for the reports of the respective processes in the IML, where we found 59 reports corresponding to the necroscopic expert exams of the victims of the pre-selected processes. Of the 59 cases, 10 were excluded because the region of injury to the victims did not fit the inclusion criterion, that is, it was in other regions of the body other than face, head and neck, information that was not present in the judgments raised in the first phase of this study. Of the 49 reports analyzed in 6 were the victims of robbery and 43 of homicide.

First, the profile of the victims was analyzed in order to make an epidemiological study.

Regarding the age of the victim, in two reports there was no mention of this characteristic, with 47 reports remaining. Of the 47 reports in which there was reference to the age of the victim, in 30 of them (62.50\%) the victim was under 40 years. We made a separation by age group according to the SSP-SP (Secretaria de Estado dos Negócios da Segurança Pública, 2021), and we observed that the majority of the victims were concentrated in the age group of 25-29 years old (20.40\%), according to Table 1. 
Table 1 - Age of the victims, in years, according to the ages of SSP-SP.

\begin{tabular}{lcc}
\hline Age (years) & n & \% \\
\hline 20 to 24 & 7 & $14.29 \%$ \\
25 to 29 & 10 & $20.41 \%$ \\
30 to 34 & 6 & $12.24 \%$ \\
35 to 39 & 6 & $12.24 \%$ \\
40 to 44 & 9 & $18.37 \%$ \\
45 to 49 & 5 & $10.20 \%$ \\
50 to 54 & 2 & $4.08 \%$ \\
55 to 59 & 0 & $0.00 \%$ \\
60 to 64 & 2 & $4.08 \%$ \\
Without & 2 & $4.08 \%$ \\
information & & $\mathbf{1 0 0 \%}$ \\
\hline Total & $\mathbf{4 9}$ & \\
\hline
\end{tabular}

Source: Own elaboration.

Regarding the gender, in the collected reports, it was verified that the majority of the victims were male (75.51\%).

Another characteristic analyzed was the color of the skin, and for that the concept brought by IBGE (Instituto Brasileiro de Geografia e Estatística a, 2021) was used, according to which "color or race is the characteristic declared by the people according to the following options: white, black, yellow, brown or indigenous". Of the 49 reports, only 1 did not describe this characteristic (the report in question corresponded to indirect examination, in which only the medical record of the victim was presented to the expert), of the remaining 48 cases, in 33 of them the victim was white (69\%), 11 were brown (23\%) and 4 were black $(8 \%)$.

In 23 (46.94\%) of the 49 reports analyzed there was no mention of the degree of education of the victim, in $19(38.78 \%)$ the victim had only the 1st degree and in 7 (14.29\%) of them the 2nd degree.

It was observed that in $7(14.29 \%)$ of the 49 cases analyzed the crime occurred in the context of domestic violence, one against the mother-in-law, one against the stepchild and the other five against a wife and / or partner. In 9 (18.37\%) cases it was evidenced that the crime was related to the use of some type of illicit drug. It is important to highlight that this information was obtained in the analyzed judgments.

In all cases, the professional who acted in the expertise was the medical examiner. The use of technical language was also observed in all the analyzed reports. The description of the lesions and the instruments that caused them was always carried out with the use of established medical-legal terms.

Among the items that must be answered by the expert in his expert's report, four of them are fixed, predetermined, that is, that appear in all the necroscopic reports. Are they: 1) was there death?; 2) what was the cause?; 3) what is the nature of the agent, instrument or method that produced it?; 4) was it produced by poison, fire, explosive, suffocation or torture, or by another insidious or cruel means?

Of the 49 reports analyzed, in only 1 of them there was no response to the standard questions, since it was a toxicological examination, complementary to the necroscopic report of the victim (that was not found), required by the police authority.

Of the remaining 48, all of them referred to the cause of death. And, in answer to the first question, "was there death?" In $100 \%$ of these the answer was: "yes, violent death."

The causes of death described were: neck injury (1), hypovolemic shock (1), traumatic brain injury (20), asphyxia (2), external acute hemorrhage (1), carbonization (1), respiratory failure, pneumonia and short-term injuries (1), anemia (5), 
polytrauma (5), hemorrhagic shock (5), fracture, neck dislocation (1), cerebral hypoxia (1), cerebral transfixation (2) and hemorrhagic shock by transfixation (2).

Regarding the presence of the description and classification of the lesions and instruments that produced them, the answer to the question "what is the nature of the agent, instrument or means that produced it?", Presented in the 48 reports in which the questions were answered, s) type (s) of instrument (s) used. It was observed that in most cases a blunt instrument (14) was used, followed by a blunt instrument (12), a cutting tool (11), a short blunt instrument (9), a cutting tool (3), a physicochemical agent (3) and, finally, biodynamic agent with only 1 case.

In 5 of the 48 reports with the instrument description there were two instruments that caused the lesion, which explains the total of 53 .

Besides these there is the possibility of extra questions, formulated by the judicial and / or police authorities. However, in only one of the 48 reports in which there was an answer to the questions, there was an extra question, which came from the police authority, which was "to check for traces of projectiles in the victim's body compatible with the cartridge case."

As for the comparison of the epidemiological results obtained in the present study with data from governmental agencies (Instituto Brasileiro de Geografia e Estatística a, 2021; Secretaria de Estado dos Negócios da Segurança Pública, 2021), the chisquare test for gender and criminal type and Fisher's exact test for age and skin color were applied, $(\mathrm{p}=0.444)$, gender $(\mathrm{p}=$ $0.071)$, skin color $(\mathrm{p}=0.054)$, and type of disease $(\mathrm{p}=0.054) .=0.103)$. Gender and skin color tended to have statistically significant differences.

\section{Discussion}

It is important to note that no published research was found in the scientific literature, that is, no surveys were found that could have their results compared to those found here. In this way, we present parallels with epidemiological data, regarding the information that allows such verification.

The number of cases judged in the year 2013 stands out because, while the average of the other years was 21 occurrences, in 2013 we observed 35 . However, we did not find any data to justify this discrepancy.

The low number found in 2017 is explained by the fact that the data presented refer to the first 8 months of the year.

The highest concentration of judged processes from the city of Araraquara (77.78\%) can be explained as a result of the population distribution of the region (Instituto Brasileiro de Geografia e Estatística b, 2021).

The distribution in relation to the criminal type is consistent with the SSP-SP26 statistics of crimes for our region. The difference found between the sample and the government data was not statistically relevant.

According to Martinez (2013) the inspection work must be based on the flexible idea of organizational management, seeking to attend to social interests and the materialization of the crime. In the present study, both in the cases of fraudulent homicide, in the jurisdiction of the Jury's Court, and in the cases of theft followed by death, references to the respective inspection reports found in the judgments occurred as a way of proving the materiality of the offense, which can be considered normal, since the crimes studied here are transient crimes, that is, crimes that leave traces and, therefore, require the examination of a body of crime as a form of prove their materiality (article 158 of the CPC) (Brasil, 1941). There were also cases in which the reports were mentioned to prove the existence of qualifiers (which causes an increase in the penalty to be applied). Thus, the awards served social interests, with the proof of the aforementioned facts.

Concerning the information on the use of the award to support the decision, in cases of intentional crimes against life (such as willful murder), such verification was not possible, since, in the case of the Jury according to item "b" of item XXXVIII of art. 5o of the Federal Constitution (Brasil, 1988) the principle of secrecy of the verdict applies, that is, the decision of the 
jurors is confidential, and breach of secrecy results in the invalidity of the proceedings. Nevertheless, it is important to emphasize that this information was not present even in cases of robbery.

It is also worth reiterating that references to information specific to the report were found, especially to justify the presence of qualifiers, as well as evidence of materiality, as already mentioned.

Comparing the statistical data of the SSP-SP (Secretaria de Estado dos Negócios da Segurança Pública, 2021) (on the profile of homicide victims in the interior of the State of São Paulo, with the sample of this work, we observed consistent results. Although gender and skin color tended to show statistically significant differences, both in government data and in this research, there is a prevalence of white and male skin color victims. The differences in the age range were not statistically relevant.

Although the data found show that in $14.28 \%$ of the cases the crimes were committed in the context of family violence and $18.36 \%$ involved illicit drug use, these values may be underestimated, since many details the circumstances in which the crimes occurred.

Although our study limited the search for expert reports to cases in which there was an injury to the face, head and neck region, which is the competence of the odontologist, in none of the analyzed reports did we observe the assistance of this professional.

According to article 165 of CPC (Brasil, 1941), whenever possible the experts will attach photographs, diagrams or drawings to represent the lesions found in the cadavers. Although the result of the research has shown that the absence of these elements in most of the reports, we can't affirm that there was no attention to this rule. Most reports given to us were copies of the report on the computer, so we did not have complete access to the whole set. From the physical reports to which we had access, all had schematic drawings and in some there were photos.

The necroscopic report is the instrument capable of proving the materiality of crimes that result in death. The reports analyzed revealed the description of the lesion and the type of instrument.

The reports were also adept at demonstrating a qualifier. As an example, part of one of the judgments demonstrating this assertion is reproduced below.

$[\ldots]$ the qualifier of the cruel environment was also sufficiently demonstrated, especially by the oral test collected and by the necroscopic examination report of fls. 53/54, which demonstrate that the offended has been subjected to intense and prolonged suffering, since he has been attacked with forceful objects, numerous times and in various parts of his body.

The location of the injury may show that the agent did not intend to kill the victim (indicative of the subjective element of the crime) when there is death, such as crimes of bodily injury followed by death, abandonment of the incapacitated person followed by death, fire, followed by death. Then the report will weigh even more. The description of the injury is indicative of the type of instrument that caused it.

The reports analyzed were able to demonstrate these elements. All of them presented a thorough analysis of the injuries of victims of violent crimes, indicating the instrument that caused them, always using terms established in Legal Medicine. In all cases where there was an injury caused by firing a firearm, for example, the tests indicated the trajectory of the projectile.

It was observed that the reports analyzed are able to assist Criminal Justice.

\section{Conclusion}

Most of the judgments analyzed referred to the expert report, and all of them referred to the award as a way of proving 
the materiality of the crime. The reports were also mentioned to prove the existence of qualifiers.

In the cases analyzed, the majority of the victims of homicide and robbery were male, white, under 40 years of age and of low schooling.

The totality of the reports presented the description and classification of the lesions and instruments that caused them. The most frequent instruments were the blunt-blunt, the blunt, and the sharp.

In general, the evaluated reports presented good quality, with technical language and detailed description of the lesions and the instruments that caused them.

Criminal expert reports tend to be of great help to the delineation of criminal justice.

Due to the large territorial extension of the country, further research with larger samples, representative of Brazil or its regions, is recommended.

\section{Acknowledgments}

The authors thank the Secretariat of Public Security of the State of São Paulo, especially the Superintendence of the Technical-Scientific Police, for the authorization and collaboration for the development of this research.

The authors thank the dentist Gabriela Eleutério Pulitano for her help in collecting the data.

Funding

This study was financed in part by the Coordenação de Aperfeiçoamento de Pessoal de Nível Superior - Brasil (CAPES) Finance Code 001. Edital Programa Ciências Forenses n. 25/2014 "Pró-Forenses".

\section{References}

Bandeira, R. O., Menezes, L. M. B., Oliveira, M. C., \& Correia, A. M. (2013) Perícias criminais odontológicas realizadas em um município de grande porte do nordeste brasileiro. $R G O .6(3): 349-55$.

Borges, D., Miranda, D., Duarte, T., Ettel, F. N. K., Guimarães, T. \& Ferreira, T. (2013) Mortes violentas no Brasil: uma análise do fluxo de informações. In: Figueiredo IS, Leme C, Lima CSL. Homicídios no Brasil: registro e fluxo de informações (pp. 329-409). Ministério da Justiça.

Bocchini, B. (2017) Brasil tem mais mortes violentas que a Síria em guerra, mostra anuário. https://agenciabrasil.ebc.com.br/direitos-humanos/noticia/201610/brasil-tem-mais-mortes-violentas-do-que-siria-em-guerra-mostra

Brasil. (1941) Código de Processo Penal brasileiro. Decreto-Lei n. 3.689, de 03 de outubro de 1941. http://www.planalto.gov.br/ccivil_03/decretolei/Del3689Compilado.htm.

Brasil. (1940) Código Penal Brasileiro. Decreto-Lei n. 2.848, de 07 de dezembro de 1940. http://www.planalto.gov.br/ccivil_03/decretolei/Del2848compilado.htm

Brasil. (1988) Constituição da República Federativa do Brasil de 1988. http://www.planalto.gov.br/ccivil_03/constituicao/constituicao.htm.

Carvalho, L. A. M. N., \& Almeida, S. S. (2020) Impacto dos laudos de perícia papiloscópica em locais de crime nas decisões judiciais. Research, Society and Development. 9(7): e110973658.

Costa, M.R. (1999) A violência urbana é particularidade da sociedade brasileira? Perspec. 13(4): 3-12.

Couto, R.S. (2011) Perícias em medicina \& odontologia legal. MedBook.

Croce, D. \& Croce Jr, D. (2012) Manual de medicina legal. (8a ed.), Saraiva.

Dahlberg, L. L. \& Krug, E. G. (2006) Violência: um problema global de saúde pública. Ciênc Saúde Colet. 11(Suppl), $1163-78$.

Dias, F. C. (2010) A prova pericial no Direito Processual Penal brasileiro. Rev Âmbito Jurídico. https://ambitojuridico.com.br/edicoes/revista-80/a-provapericial-no-direito-processual-penal-brasileiro/

Diniz, D., Penalva, J., \& Galvão, M. (2013) O impacto dos laudos periciais no julgamento de homicídio de mulheres em contexto de violência doméstica ou familiar no Distrito Federal. In: Figueiredo, I. S., Leme, C., \& Lima, C. S. L. Homicídios no Brasil: registro e fluxo de informações (pp. 143-93). Ministério da Justiça.

Espindola, A. (2008) Laudo pericial e outros documentos técnicos. Brasília-DF. https://www.conteudojuridico.com.br/consulta/artigos/16240/laudo-pericial-eoutros-documentos-tecnicos\#: :text=O\%20laudo\%20pericial\%20\%C3\%A9\%20uma,resultado\%20do\%20trabalho\%20do\%20perito. 
Estelita, H., Ferreira, C. C. \& Matsuda, F. E. (2013) O Homicídio em três cidades brasileiras. In: Figueiredo, I. S., Leme, C., \& Lima, C. S. L. Homicídios no Brasil: registro e fluxo de informações (pp. 9-70). Brasília: Ministério da Justiça.

Fórum Brasileiro de Segurança Pública. (2019) 130 Anuário Brasileiro de Segurança Pública: https://forumseguranca.org.br/wpcontent/uploads/2019/10/Anuario-2019-FINAL_21.10.19.pdf

França, G. V. (2017) Medicina legal. (11a ed.), Guanabara Koogan.

Gomes, L. F. (2015) Brasil tem 19 das 50 cidades mais violentas do mundo Jus Navigandi. Retrieved from https://jus.com.br/artigos/36182/brasil-tem-19-das50-cidades-mais-violentas-do-mundo.

Greco, R. (2020) Código Penal Comentado. (14a ed.), Impetus.

Instituto Brasileiro de Geografia e Estatística a. (2021) Indicadores sociais mínimos: conceitos. https://www.ibge.gov.br/estatisticas/sociais/populacao/17374indicadores-sociais-minimos.html?=\&t=o-que-e.

Instituto Brasileiro de Geografia e Estatística b. (2021) Brasil em síntese: panorama das cidades https://cidades.ibge.gov.br/brasil/sp/araraquara/panorama.

Krymchantowski, A. V., Calhaum, L. B., Ancillotti, R., Greco, R. \& Douglas, W. (2011) Medicina legal à luz do direito penal e do direito processual penal. (10a ed.), Impetus.

Lopes, T. (2020) O Laudo Pericial na formação da convicção na Justiça Criminal. Jus Navigandi. https://jus.com.br/artigos/82792/o-laudo-pericial-na-formacaoda-conviccao-na-justica-criminal

Magnabosco, C. D., Cassemiro, P. M. S. \& Souza, P. A. (2020) Registros de violência contra a mulher no Instituto Médico Legal em Lages, no Estado de Santa Catarina, Brasil, no período de 2004 a 2012. Research, Society and Development. 9(9), e842997817.

Martinez, S. B. (2013) A efetividade do laudo pericial: um estudo sobre a influência do laudo pericial de informática na decisão judicial. [dissertação de mestrado]. Fundação Getúlio Vargas.

Oliveira, W. F. (2008) Violência e saúde coletiva: contribuições teóricas das ciências sociais à discussão sobre o desvio. Saúde Soc. 17(3): 42-53.

Oliveira, M. F., Oliveira, D. F., Teles, J. C. P., Limeira, R. B. \& Silva, L. N. B. (2021) A presença da Medicina Legal como disciplina nos cursos de Direito: análise de sua importância para o Direito Processual Penal e a expertise do sistema de justiça brasileiro, aludindo ao caso Isabella Nardoni. Research, Society and Development. 10(1): e35210111653.

Pereira, A. S., Shitsuka, D. M., Parreira, F. J. \& Shitsuka, R. (2018). Metodologia da pesquisa científica. UFSM. https://repositorio.ufsm.br/bitstream/ha ndle/1/15824/Lic_Computacao_Metodologia-Pesquisa-Cientifica.pdf?sequence=1

Reichenheim, M. E., Souza, E. R., Moraes, C. L., Mello Jorge, M. H., Silva, C. M. \& Minayo, M. C. S. (2011) Violência e lesões no Brasil: o efeito, os progressos realizados e os desafios à frente. Lancet. 377:1962-75.

Ribeiro, M. L. S. \& Laureano Filho, J. R. (2020) Lesões fatais em região crânio-facial em mulheres: análise post-mortem. Research, Society and Development. 9(12): e15491211017.

Secretaria de Estado dos Negócios da Segurança Pública. (2021) Estatísticas. http://www.ssp.sp.gov.br/Estatistica/Mapas.aspx.

Serra, M. C. \& Fernandes, C. M. S. (2013) Medicina legal. In: Polícia civil do estado da Bahia (pp. 1-24). Gran Cursos.

Silva, M. (1997) Compêndio de odontologia legal. Medsi.

Superintendência da Polícia Técnico Científica. (2021) Institucional: instituto de criminalística e instituto médico legal. http://www.policiacientifica.sp.gov.br.

Vanrell, J. P. (2019) Odontologia legal \& Antropologia Forense. (3a ed.), Guanabara Koogan. 